\title{
Dino Otter, Émile Verhaeren. Un miroir à mille facettes du multiple univers
}

\section{Alessandra Marangoni}

\section{(2) OpenEdition}

1 Journals

\section{Edizione digitale}

URL: http://journals.openedition.org/studifrancesi/9017

DOI: 10.4000/studifrancesi.9017

ISSN: 2421-5856

\section{Editore}

Rosenberg \& Sellier

\section{Edizione cartacea}

Data di pubblicazione: 1 octobre 2008

Paginazione: 485-486

ISSN: 0039-2944

\section{Notizia bibliografica digitale}

Alessandra Marangoni, «Dino Otter, Émile Verhaeren. Un miroir à mille facettes du multiple univers», Studi Francesi [Online], 155 (LII | II) | 2008, online dal 30 novembre 2015, consultato il 07 janvier 2021. URL: http://journals.openedition.org/studifrancesi/9017 ; DOI: https://doi.org/ERREUR PDO dans / localdata/www-bin/Core/Core/Db/Db.class.php L.34 : SQLSTATE[HYO00] [2006] MySQL server has gone away

Questo documento è stato generato automaticamente il 7 janvier 2021.

\section{(c) (i) $\odot$}

Studi Francesi è distribuita con Licenza Creative Commons Attribuzione - Non commerciale - Non opere derivate 4.0 Internazionale. 


\title{
Dino Otter, Émile Verhaeren. Un miroir à mille facettes du multiple univers
}

\author{
Alessandra Marangoni
}

\section{NOTIZIA}

DINO OTTER, Émile Verhaeren. Un miroir à mille facettes du multiple univers, Torino, Silvio Zamorani editore, 2005, pp. 94.

1 Il saggio, preceduto da una presentazione di E. GIACHERY e da un'introduzione di G. SCALISE, costituisce l'ampliamento di uno studio nato nel 1945. D. Otter vi esamina con passione alcuni momenti salienti della poesia di Verhaeren, fiammingo di lingua francese: la perdita della fede giovanile sostituita da un sentimento unitario del mondo; il passaggio da una «mistica orfica» a una «mistica della vita», con la rivelazione del personaggio collettivo che è la folla; gli accenti mistici della poesia amorosa de Les heures claires. Nel fare questo, l'A. passa in rassegna (talora per prenderne le distanze su singoli punti) alcuni dei maggiori contributi critici su Verhaeren. È anche analizzato il possibile senso della Lettera del Giovane Lavoratore, indirizzata da Rilke al Signor V. (Verhaeren).

2 Allegato al volumetto, un CD contenente venti poesie di Verhaeren, scelte e interpretate da Dino Otter. 